\title{
Impact of a 21-Gene Recurrence Score Test on the Choice of Adjuvant Chemotherapy for Hormone Receptor-positive Early-stage Breast Cancer: A Prospective Study
}

\author{
YINDUO ZENG ${ }^{1}$, QIAN LI ${ }^{1}$, TAO QIN ${ }^{2}$, SHUNRONG LI $^{1}$, LIANG JIN ${ }^{1}$, JIANNAN WU ${ }^{1}$, KAI CHEN ${ }^{1}$, \\ HERAN DENG ${ }^{1}$, NANYAN RAO ${ }^{1}$, QIANG LIU ${ }^{1}$, FENGXI SU ${ }^{1}$, WEIJUAN JIA ${ }^{1}$ and HERUI YAO ${ }^{1,2}$ \\ ${ }^{1}$ Guangdong Provincial Key Laboratory of Malignant Tumor Epigenetics and Gene Regulation, \\ Breast Cancer Tumor Center, and ${ }^{2}$ Department of Medical Oncology, \\ Sun Yat-sen Memorial Hospital, Sun Yat-sen University, Guangzhou, P.R. China
}

\begin{abstract}
Background: Studies have recommended a 21-gene recurrence score $(R S)$ to optimize adjuvant treatment for patients with early-stage breast cancer (EBC) with hormone receptor-positive $\left(\mathrm{HR}^{+}\right)$and human epidermal growth factor receptor-2 negative (HER2-) tumors. This study aimed to prospectively evaluate the impact of this $R S$ in Chinese patients with breast cancer. Patients and Methods: We prospectively collected 227 patients with $E B C$ with estrogen receptor-positive $\left(E R^{+}\right)$and HER2- tumors. We used one-way analysis of variance to compare the distribution of different risk groups based on a 21-gene RS assay. A Kruskal-Wallis test and either a chi-square or Fisher's exact test were used as appropriate to compare continuous and categorical variables, respectively. Results: Of the 227 eligible women enrolled, $61.2 \%, 30 \%$, and $8.8 \%$ of patients were in the low $(\leq 17)$, intermediate (18-30) and high $(\geq 31)$ RS groups, respectively. Of the patients with a low $R S, 74.8 \%$ were overestimated into the intermediate-risk group by St. Gallen risk. The overall impact of the 21-gene RS was reduced use of chemotherapy (78/227, 34.4\%). In addition, Ki67 expression was positively associated with the 21-gene $R S(R=0.68)$. Conclusion: Among patients with $E R^{+} / H E R 2^{-} E B C$, the 21 gene RS was an effective method for making a chemotherapy decision. Ki67 was associated with 21-gene RS.
\end{abstract}

Breast cancer is the leading cause of cancer death in women, followed by lung cancer, in China, with $12.2 \%$ annual new

Correspondence to: Herui Yao and Weijuan Jia, No.107 Yanjiang Road Guangzhou, Guangdong, 510120. P.R. China. E-mail: yaoherui@163.com (Herui Yao) and jiaweijuan@aliyun.com (Weijuan Jia)

Key Words: Breast cancer, early stage, adjuvant chemotherapy, 21gene score, Ki67. cases and $9.6 \%$ annual deaths (1). In general, patients undergo primary treatment with a curative intent when they are diagnosed at an early stage. Adjuvant chemotherapy reduces breast cancer recurrence and cancer-related death. Chemotherapy results in an absolute benefit of $3-10 \%$, reducing tumor recurrence through the use of polychemotherapy in all common breast cancer types, especially in younger patients (2). Traditionally, molecular markers, tumor grade, tumor size, lymph node status and age at diagnosis have been regarded as important factors having an impact on a physician's decision to administer chemotherapy to patients with breast cancer (3-5). However, early-stage breast cancer (EBC) is a heterogeneous disease, not only in its characteristics and clinical course, but also in its molecular profile (6).

Currently, some patients can avoid chemotherapy based on the European Society for Medical Oncology (7), the American Society of Clinical Oncology, the National Comprehensive Cancer Network (8) and the St. Gallen International Expert Consensus (9). Both the NSABP-B14 and SWOG-8814A studies indicated that patients with estrogen receptor-positive $\left(\mathrm{ER}^{+}\right)$breast cancer with a low 21-gene recurrence score (RS) receive no benefit from adjuvant chemotherapy (10). Patients with a high 21-gene $\mathrm{RS}$ in the study benefited from chemotherapy, whereas patients with a low score did not appear to benefit from the addition of chemotherapy regardless of the number of positive lymph nodes (11). Therefore, using precise methods, such as the 21-gene RS assay to select adjuvant chemotherapy for those with luminal non-human epidermal growth factor receptor- 2 positive (non-HER2 ${ }^{+}$) subtypes of breast cancer is necessary (12).

Several studies have demonstrated that the 21-gene RS aids in decision making for adjuvant chemotherapy in $\mathrm{ER}^{+} / \mathrm{HER} 2^{-}$ EBC (13-15). This 21-gene RS-guided chemotherapy decision-making approach has led to the substantial modification of adjuvant chemotherapy in node-negative and node-positive $\mathrm{ER}^{+}$breast cancer $(6,16)$. Results have shown 
that those with a lower score [odds ratio $(\mathrm{OR})=0.36$ ] are in a high-risk group with chemotherapy, while those with a higher score $(\mathrm{OR}=3.71)$ are in a low-risk group with chemotherapy (17). Thus, there has been an increasing tendency to use the 21 -gene RS, with application rates increasing from $1.1 \%$ to $10.1 \%$ in the United States from 2005 to 2009 among intermediate-risk patients with $\mathrm{ER}^{+}$, node-negative disease and tumors larger than $1 \mathrm{~cm}$ (17). Although a study with a similar methodology reported the use of the 21-gene RS test for Chinese patients with breast cancer, the small sample size included few patients with high Ki67 expression and excluded patients with node-positive disease (18). Thus, we lack comprehensive data about the 21-gene RS assay in China both in node-negative and -positive breast cancer cases, and the role of the 21 -gene $\mathrm{RS}$ assay in a Chinese population warrants further investigation.

In this prospective study, we assessed whether the 21-gene RS test administered after breast surgery helped optimize the adjuvant therapy strategy. In addition, we aimed to explore the correlation between Ki67 expression and the 21-gene RS assay.

\section{Patients and Methods}

The study was approved by the Institutional Review Board of the Sun Memorial Hospital. Each patient signed a gene testing informed-consent form, and the testing was performed to provide additional information for physicians regarding the selection of adjuvant chemotherapy.

Patients. This prospective study enrolled hormone receptor-positive patients who participated in the 21-gene RS test. All of the patients were staged according to the American Joint Committee on Cancer (seventh edition) TNM Staging System for Breast Cancer (19).

A total of 227 patients with stage I-II breast cancer with ER $^{+} /$HER2- tumors were included between August 14, 2013 and August 30. 2016 at the Sun Yat-sen Memorial Hospital. The patients enrolled were diagnosed with $\mathrm{EBC}$ that was $\mathrm{ER}^{+}$and/or progesterone receptor-positive $\left(\mathrm{PR}^{+}\right)$and did not overexpress HER2. The patients had to meet the National Comprehensive Network guidelines for the recommendation of adjuvant chemotherapy (20), including a primary tumor size of 1.1 to 5.0 $\mathrm{cm}$ in the largest dimension for a tumor of any grade or a size of 0.6 to $1.0 \mathrm{~cm}$ in the largest dimension for a tumor with an intermediate or high histological grade. Other eligibility criteria included age $\geq 18$ years and a good performance status (East Collaboration of Oncology Group Performance Status Scale, 0-1). There was no contraindication for receiving systemic chemoendocrine therapy. Physicians and patients had to confirm that the patients were principally willing to consider their initial recommendation and decision.

The grading of the tumor and the histological classification were based on the World Health Organization (WHO) criteria (21). The ER and PR status of the primary tumor was determined by immunohistochemistry, and the percentage of positive staining was evaluated. The patients were considered HER2 ${ }^{+}$if the HER2 protein measured a $3+$ intensity when examined using immunohistochemistry
Table I. General characteristics of all of the patients included in this study.

\begin{tabular}{|c|c|c|c|}
\hline Characteristic & All $(\mathrm{N}=227)$ & N0 $(\mathrm{N}=206)$ & $\mathrm{N} 1(\mathrm{~N}=21)$ \\
\hline Mean age, years (range) & $49(23-77)$ & $48(23-77)$ & $55(38-73)$ \\
\hline \multicolumn{4}{|l|}{ Tumor size, $\mathrm{n}(\%)$} \\
\hline$\leq 2 \mathrm{~cm}$ & 164 & $149(90.9)$ & $15(9.1)$ \\
\hline$>2 \mathrm{~cm}$ & 63 & $57(90.5)$ & $6(9.5)$ \\
\hline \multicolumn{4}{|l|}{ Grade, n (\%) } \\
\hline I & 22 & $22(100)$ & 0 \\
\hline II & 120 & $108(90.0)$ & $12(10.0)$ \\
\hline III & 48 & $43(90.0)$ & $5(10.0)$ \\
\hline Not applicable & 37 & $33(89.2)$ & $4(10.8)$ \\
\hline \multicolumn{4}{|l|}{ Histological type, n (\%) } \\
\hline IDC & 199 & $179(90)$ & $20(10.0)$ \\
\hline ILC & 9 & $9(100)$ & 0 \\
\hline Other & 19 & $18(94.7)$ & $1(5.3)$ \\
\hline \multicolumn{4}{|l|}{$\mathrm{PR}, \mathrm{n}(\%)$} \\
\hline Positive & 213 & $194(91.1)$ & $19(8.9)$ \\
\hline Negative & 14 & $12(85.7)$ & $2(14.3)$ \\
\hline \multicolumn{4}{|l|}{ Ki67, n (\%) } \\
\hline$<15 \%$ & 55 & $51(92.7)$ & $4(7.3)$ \\
\hline$\geq 15 \%$ & 172 & $155(90.1)$ & $17(9.9)$ \\
\hline \multicolumn{4}{|l|}{ 21-Gene RS } \\
\hline Mean & 18 & 18 & 17 \\
\hline Low $(\leq 17), \mathrm{n}(\%)$ & 139 & $126(90.7)$ & $13(9.4)$ \\
\hline Intermediate (18-30), n (\%) & 68 & $61(89.7)$ & $7(10.3)$ \\
\hline High $(\geq 31), \mathrm{n}(\%)$ & 20 & $19(95.0)$ & $1(5)$ \\
\hline
\end{tabular}

IDC: Invasive ductal carcinoma; ILC: invasive lobular carcinoma; PR: progesterone receptor; RS: recurrence score; IHC: immunohistochemistry.

or upon amplification of the HER2/neu gene using fluorescence in situ hybridization. The cut-off for Ki67 was selected as $20 \%$ as reported in a previous study (22).

Treatment recommendations. Adjuvant treatment was initially recommended for each patient by their oncologist based on our routine clinical practice. The St. Gallen risk factors for making a chemotherapy decision included age younger than 35 years, a tumor larger than $2 \mathrm{~cm}$, grade II-III, the presence of extensive peritumoral vascular invasion, and node-positive disease (23). Subsequently, the treatment decision was made by an oncologist after obtaining the results of the 21-gene RS assay. The concordance of the recommendations made according to the 21 -gene RS assay and clinical practice was calculated.

21-Gene assays. All of the candidates underwent a 21-gene RS test, which is a new method using RNA extracted from formalin-fixed paraffin-embedded tissue performed by SurExam, Guangzhou, China. Branch DNA liquid chip was used to detect 21 genes: marker of proliferation Ki-67 (MKI67), aurora kinase A (STK15), survivin, cyclin B1 (CCNB1), v-myb avian myeloblastosis viral oncogene homolog-like 2 (MYBL2), glutathione S-transferase mu 1 (GSTM1), B-cell lymphoma 2-associated athanogene (BAG1), matrix metallopeptidase 11 (MMP11), cathepsin L2 (CTSL2), estrogen receptor $(E R)$, progesterone receptor $(P R)$, B-cell lymphoma 2 (BCL2), signal peptide, CUB domain, epidermal growth factor-like 
Table II. Clinical and pathological characteristics in relation to the 21-gene recurrence score (RS).

\begin{tabular}{|c|c|c|c|c|c|}
\hline \multirow[t]{2}{*}{ Characteristic } & \multirow[t]{2}{*}{ Total } & \multicolumn{3}{|c|}{ 21-Gene RS, n (\%) } & \multirow[t]{2}{*}{$p$-Value } \\
\hline & & Low & Intermediate & High & \\
\hline \multicolumn{6}{|l|}{ Age, years } \\
\hline Mean & $49(23-77)$ & 49 & 48 & 52 & 0.342 \\
\hline Median & $48(23-77)$ & 48 & 45 & 53 & \\
\hline Age, years & & & & & 0.13 \\
\hline$\leq 35$ & 16 & $6(37.5 \%)$ & $8(50.0 \%)$ & $2(12.5 \%)$ & \\
\hline$>35$ & 211 & $133(63.0 \%)$ & $60(28.4 \%)$ & $18(8.5 \%)$ & \\
\hline Menopausal status & & & & & 0.24 \\
\hline Premenopausal & 202 & $120(59.4 \%)$ & $64(31.7 \%)$ & $18(8.9 \%)$ & \\
\hline Postmenopausal & 25 & $19(76.0 \%)$ & $4(16.0 \%)$ & $2(8.0 \%)$ & \\
\hline Histology & & & & & 0.69 \\
\hline IDC & 199 & $119(59.8 \%)$ & $62(31.2 \%)$ & $18(9.0 \%)$ & \\
\hline ILC & 9 & $7(77.8 \%)$ & $2(22.2 \%)$ & 0 & \\
\hline Other & 19 & $13(68.4 \%)$ & $4(21.1 \%)$ & $2(10.5 \%)$ & \\
\hline Tumor size & & & & & 0.02 \\
\hline$\leq 2 \mathrm{~cm}$ & 164 & $108(65.9 \%)$ & $46(28.0 \%)$ & $10(6.1 \%)$ & \\
\hline$>2 \mathrm{~cm}$ & 63 & $31(49.2 \%)$ & $22(34.9 \%)$ & $10(15.9 \%)$ & \\
\hline Tumor grade & & & & & $<0.001$ \\
\hline I & 22 & $21(95.5 \%)$ & $1(5 \%)$ & 0 & \\
\hline II & 120 & $75(62.5 \%)$ & $40(33.3 \%)$ & $5(4.2 \%)$ & \\
\hline III & 48 & $15(31.3 \%)$ & $20(41.7 \%)$ & $13(27.1 \%)$ & \\
\hline Not applicable & 37 & $28(75.7 \%)$ & $7(18.9 \%)$ & $2(5.4 \%)$ & \\
\hline ER (continue, mean) & 86 & 87 & 86 & 72 & $<0.001$ \\
\hline PR (continue, mean) & 56 & 64 & 47 & 23 & $<0.001$ \\
\hline HER 2 by IHC & & & & & 0.04 \\
\hline 0 & 36 & $22(61.1 \%)$ & $7(19.4 \%)$ & $7(19.4 \%)$ & \\
\hline $1+$ & 91 & $50(54.9 \%)$ & $34(37.4 \%)$ & $7(7.7 \%)$ & \\
\hline $2+$ & 100 & $67(67.0 \%)$ & $27(27.0 \%)$ & $6(6.0 \%)$ & \\
\hline $3+$ & & & & & \\
\hline Ki67 & & & & & $<0.001$ \\
\hline$\leq 20 \%$ & 154 & $113(81.3 \%)$ & $34(22.1 \%)$ & $7(4.5 \%)$ & \\
\hline$>20 \%$ & 73 & $26(35.6 \%)$ & $34(50.0 \%)$ & $13(17.8 \%)$ & \\
\hline
\end{tabular}

IDC: Invasive ductal carcinoma; ILC: invasive lobular carcinoma; PR: progesterone receptor; RS: recurrence score; IHC: immunohistochemistry.

2 (SCUBE2), CD68 molecule (CD68), growth factor receptor-bound protein 7 (GRB7), $\beta$-actin $(A C T B)$, glyceraldehyde-3-phosphate dehydrogenase $(G A P D H)$, glucuronidase, beta $(G U S)$, large ribosomal protein P0 (RPLP0), transferrin receptor (TFRC) and HER2/NEU. The RS was calculated based on the expression level of the genes and ranged from 0 to 100 . Patients with a score of 0 to 17 were assigned to the low-risk group; those with a score of 18 to 30 were assigned to the intermediate-risk group; and those with a score of 31 or more were assigned to the high-risk group.

Statistical analysis. A descriptive analysis was performed for the demographic and clinical characteristics of the patients. A scatter diagram was used to demonstrate the distribution of the 21-gene RS result and Ki67 expression. One-way analysis of variance (ANOVA) was used to compare the different groups. A Kruskal-Wallis test and either a chi-square or a Fisher's exact test were used, as appropriate, to compare the continuous and categorical variables, respectively. The statistical analyses were performed with SPSS software version 19.0 (IBM Corp., Armonk, NY, USA). The acceptance of statistical significance was set at $p<0.05$.

\section{Results}

Patient and tumor characteristics. A total of 227 female patients with breast cancer were enrolled in this study. The median age of all of patients was 48 years (range $=23-77$ years). The complete patient and tumor characteristics are listed in Table I. Most patients had lymph node-negative disease.

Distribution of 21-gene RS in all patients. The distribution of the 21-gene RS is presented in Figure 1. The mean \pm SD of the 21-gene RS was 17.8 \pm 9.1 . According to the RS cut-off values, patients were defined as having low $(\leq 17)$, intermediate $(18-30)$ or high $(\geq 31)$ risk. A total of $61.2 \%$ $(139 / 227), 30.0 \%(68 / 227)$ and $8.8 \%(20 / 227)$ of the patients were categorized as having low, intermediate, and high risk, respectively. The distribution of patients according to clinicopathological characteristics is listed in Table II. 


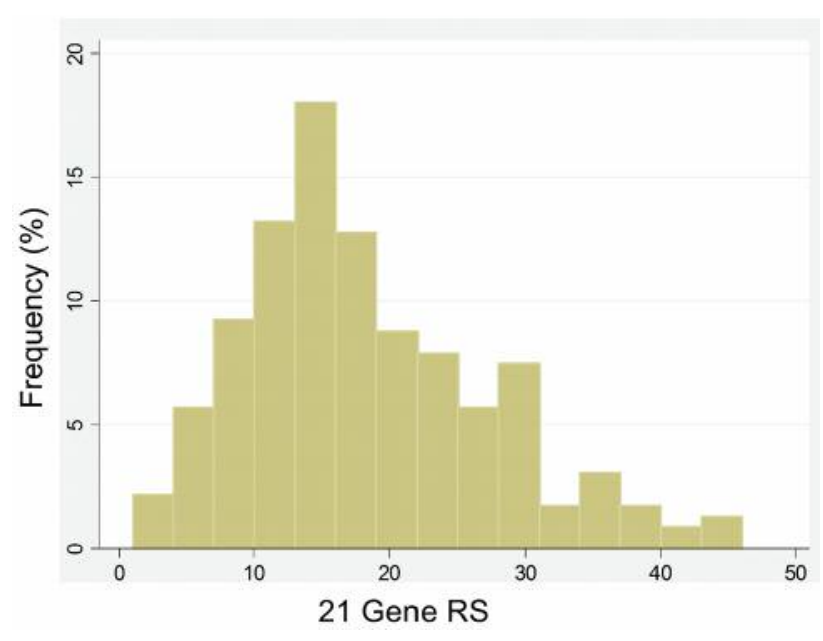

Figure 1. Distribution of the 21-gene recurrence score (RS) for all of the patients.

Table III. Concordance between 21-gene recurrence score (RS) and the 2007 St. Gallen criteria.

\begin{tabular}{lccc}
\hline & & \multicolumn{2}{c}{ St. Gallen } \\
\cline { 3 - 4 } Risk group defined by RS & Total & Low, n (\%) & Intermediate, n (\%) \\
\hline Low & 139 & $35(25.2 \%)$ & $104(74.8 \%)$ \\
Intermediate & 68 & $5(7.4 \%)$ & $63(92.6 \%)$ \\
High & 20 & 0 & $20(100 \%)$ \\
Total & 227 & $40(17.6 \%)$ & $187(82.4 \%)$ \\
$p$-Value & & \multicolumn{2}{c}{$<0.001$} \\
\hline
\end{tabular}

Among the patients with high Ki67 expression, the majority of patients were in the low-risk group (81.3\%), while only $4.5 \%$ patients with low Ki67 expression were in the highrisk group.

Furthermore, we demonstrated the concordant distribution of the patients between the 21-gene RS and the St. Gallen risk group (23), as shown in Table III. The results show that no patient in the RS high-risk group was underestimated. The concordance of distinguishing low-risk breast cancer between the 21-gene RS and the St. Gallen risk was relatively low, which was categorized as low risk by the clinical characteristics of the tumor. Regarding the determination of the intermediate-risk group, the concordance of the 21-gene RS and the St. Gallen risk group was $92.6 \%$. In the RS intermediate group, $7.4 \%$ of the patients were underestimated as the St. Gallen low-risk group. However, $74.8 \%$ of patients in the low-RS group were overestimated to the intermediaterisk group by the St. Gallen risk group.

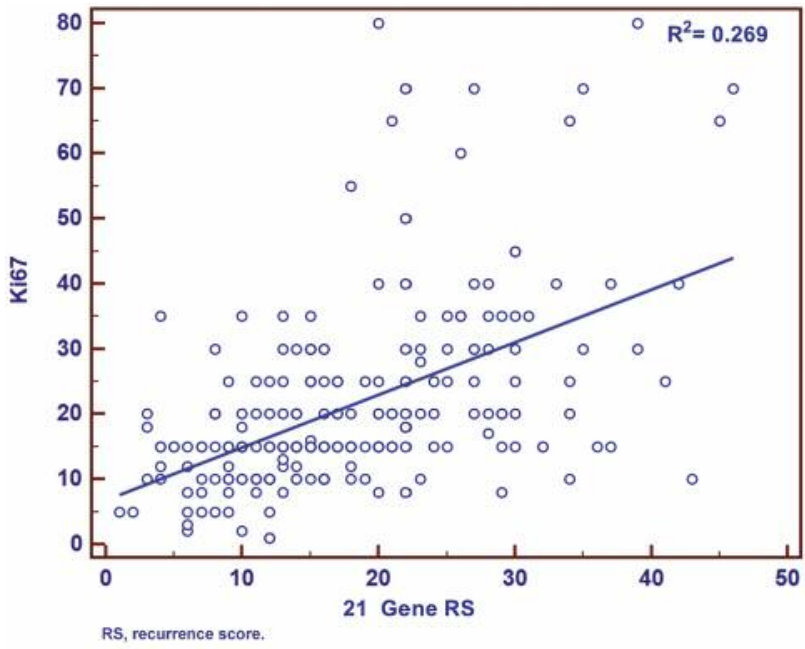

Figure 2. Scatter plot showing the correlation between the 21-gene recurrence score $(R S)$ and Ki67 expression.

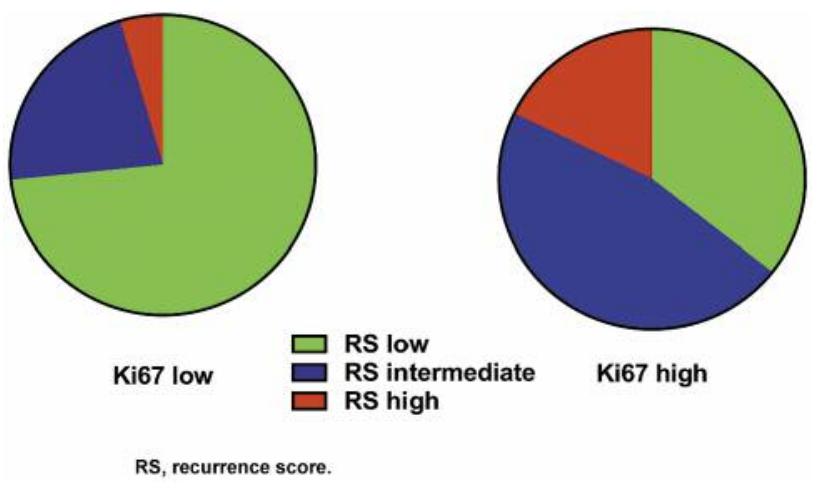

Figure 3. Distribution of the 21-gene risk groups stratified by Ki67 expression.

Correlation between the 21-gene RS and clinical risk factors. The tumor grade and tumor size significantly positively correlated with the 21-gene RS, while expression of ER and PR were negatively correlated with RS (Table IV). The correlation analysis and scatter plot shows that Ki67 expression was positively correlated with the 21-gene RS (Figure 2). Subsequently, all of the patients were divided into Ki67-low and Ki67-high expression groups. Only $4.55 \%$ of the patients were defined as high-risk by RS in the Ki67-low expression subgroup. In contrast, $17.81 \%$ of the patients were defined as high-risk in the Ki67-high expression subgroup (Figure 3). This finding suggests that Ki67 might be a potential biomarker for predicting the result of the 21gene RS assay. 
A

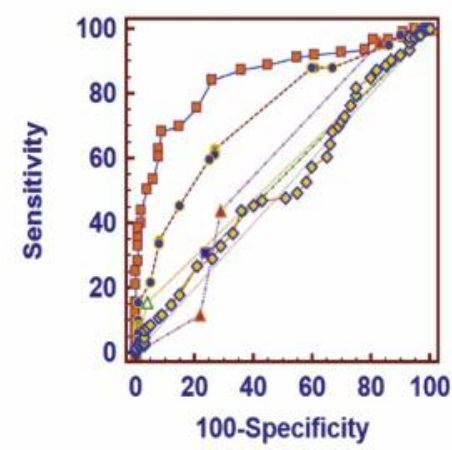

B

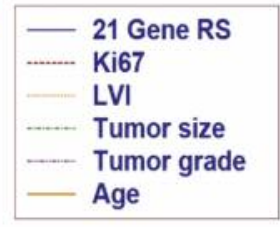

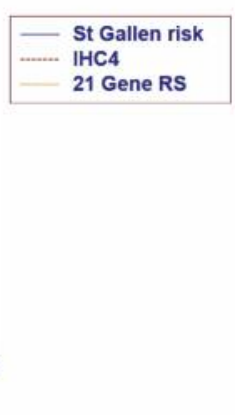

Figure 4. Comparison of the impact of different prognostic methods on the physicians' choice of chemotherapy. RS: Recurrence score, LVI: lymphovascular invasion, IHC4: immunohistochemical prognostic model.

Table IV. Correlation between variables ( $R^{2}$ value).

\begin{tabular}{|c|c|c|c|c|c|c|}
\hline & ER (IHC) & PR (IHC) & Ki67 & 21-Gene RS & Age & Size \\
\hline PR (IHC) & $0.12^{*}$ & & & & & \\
\hline Ki67 & $-0.27 * *$ & -0.09 & & & & \\
\hline 21-Gene RS & $-0.25^{* *}$ & $-0.38 * *$ & $0.52 * *$ & & & \\
\hline Age & $0.21 * *$ & $0.23 * *$ & -0.03 & -0.06 & & \\
\hline Size & 0.06 & 0.04 & 0.03 & 0.02 & -0.03 & \\
\hline Grade & -0.10 & $-0.22 * *$ & 0.16 & $0.13^{*}$ & $0.18 * *$ & -0.02 \\
\hline
\end{tabular}

ER: Estrogen receptor; PR: progesterone receptor; RS: recurrence score; IHC: immunohistochemistry. Significant at $* p<0.1, * * p<0.05$.

Impact of the 21-gene RS on chemotherapy decision making. To identify which factors may help physicians make a chemotherapy decision, we used a receiver operating characteristic (ROC) curve to compare the 21-gene RS with other risk factors, including Ki67 level, tumor size, tumor grade, lymphovascular invasion and age. We found that the 21-gene RS gave a better area under the curve (AUC) than the St. Gallen risk score $(p<0.0001$, Figure 4). Immunohistochemical prognostic model (IHC4) is also used to predict tumor recurrence and metastasis (3). Our study indicated that the 21 -gene $\mathrm{RS}$ test $(\mathrm{AUC}=0.85$ ) was superior to both the St. Gallen risk stratification $(\mathrm{AUC}=0.62)$ and IHC4 (AUC=0.70) $\quad(p<0.001) \quad$ models in making chemotherapy decision.

Distribution of the chemotherapy recommendation before and after the 21-gene test. To evaluate the expected value of the 21-gene RS in affecting the physicians' selection of chemotherapy, we addressed the change of the chemotherapy decision after the 21 -gene RS test. Of the 227 patients, a negative recommendation was made for 40 patients (17.6\%),

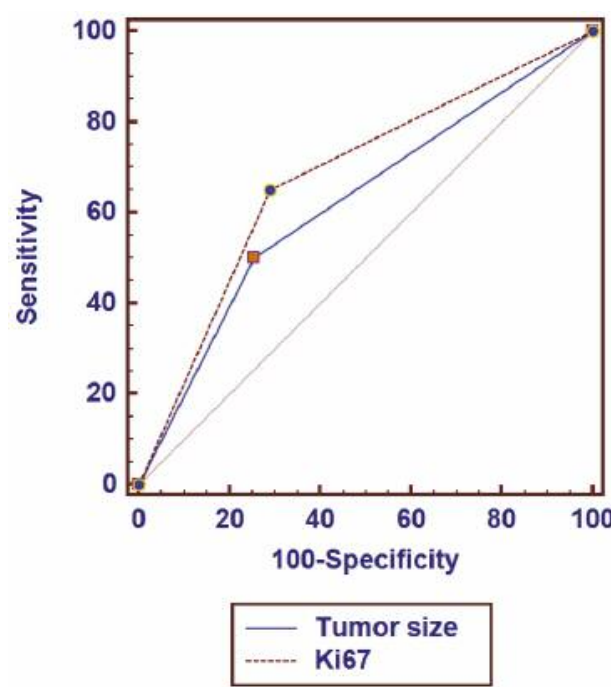

Figure 5. Ki67 expression and tumor size are associated with a high 21gene recurrence score $(R S)$.

whilst chemotherapy was recommended for $82.4 \%$ of patients (Table V). However, $13.6 \%$ of the patients with grade I tumors were also recommended chemotherapy. There is no doubt that patients with grade II-III were selected to receive adjuvant chemotherapy before the 21 -gene RS test.

After the 21-gene RS test, the distribution of chemotherapy was slightly different from that before the test (Table VI). In total, 127 out of the 227 (55.9\%) patients had a positive post21-gene RS test chemotherapy recommendation, and 80 out of the $127(63.0 \%)$ patients had an intermediate or high risk test score. In total, 47 (33.8\%) of the low-risk patients, 60 $(88.2 \%)$ of the intermediate-risk patients, and $20(100 \%)$ of the high-risk patients received adjuvant chemotherapy. 
Table V. Distribution of pre-21-gene test chemotherapy recommendations.

\begin{tabular}{lccc}
\hline & Total, $\mathrm{n}$ & Pre-test chemotherapy decision, $\mathrm{n}(\%)$ \\
\cline { 3 - 4 } & $(\mathrm{n}=227)$ & $\begin{array}{c}\text { Recommended } \\
(\mathrm{n}=187,82.4 \%)\end{array}$ & $\begin{array}{c}\text { Not recommended } \\
(\mathrm{n}=40,17.6 \%)\end{array}$ \\
\hline Grade & & & \\
I & 22 & $3(13.6 \%)$ & $19(86.4 \%)$ \\
II & 120 & $120(100 \%)$ & 0 \\
III & 48 & $48(100 \%)$ & 0 \\
Not applicable & 37 & $16(43.2 \%)$ & $21(56.8 \%)$ \\
21-Gene RS & & & \\
Low & 139 & $104(78.4 \%)$ & $35(25.2 \%)$ \\
Intermediate & 68 & $63(92.6 \%)$ & $5(7.5 \%)$ \\
High & 20 & $20(100 \%)$ & 0 \\
\hline
\end{tabular}

RS: Recurrence score.

Table VI. Distribution of the post-21-gene test chemotherapy decision by grade, age, and American Joint Committee on Cancer (AJCC) stage.

\begin{tabular}{lccc}
\hline Variable & Total, $\mathrm{n}$ & $\begin{array}{c}\text { Recommended, } \\
\mathrm{n}(\%)\end{array}$ & $\begin{array}{c}\text { Not recommended, } \\
\mathrm{n}(\%)\end{array}$ \\
\hline Grade & 227 & $127(55.9 \%)$ & $100(44.1 \%)$ \\
I & 22 & $5(22.7 \%)$ & $17(77.3 \%)$ \\
II & 120 & $66(55.0 \%)$ & $54(45.0 \%)$ \\
III & 48 & $41(85.4 \%)$ & $7(14.6 \%)$ \\
Not applicable & 37 & $15(40.5 \%)$ & $22(59.5 \%)$ \\
Age & & & \\
$\quad \leq 35$ Years & 16 & $11(68.8 \%)$ & $5(31.3 \%)$ \\
$>35$ Years & 211 & $116(55.0 \%)$ & $95(45.0 \%)$ \\
AJCC stage & & & \\
IA & 148 & $64(43.2 \%)$ & $84(56.8 \%)$ \\
IB & 68 & $53(77.9 \%)$ & $15(22.1 \%)$ \\
IIA & 11 & $10(90.9 \%)$ & $1(9.1 \%)$ \\
21-Gene RS & & & \\
Low & 139 & $47(33.8 \%)$ & $92(66.2 \%)$ \\
Intermediate & 68 & $60(88.2 \%)$ & $8(11.8 \%)$ \\
High & 20 & $20(100 \%)$ & 0 \\
\hline
\end{tabular}

RS: Recurrence score.

Following the 21-gene RS test, 100 patients (44.1\%) had a negative post-21-gene RS test chemotherapy recommendation, of which $92(66.2 \%)$ had a low-risk test score.

Change in the treatment decision by test score, pre- to post21 -gene RS test. In total, 78 patients $(34.4 \%)$ had a change in the chemotherapy recommendation after the 21-gene RS test, including $85.9 \%(67 / 78)$ of the low-risk score patients and $14.1 \%(11 / 78)$ of the intermediate-risk score patients (Table VII). For 69 out of the $78(88.5 \%)$ patients, the treatment recommendation was changed from chemotherapy to no chemotherapy based on the 21-gene RS test. Additionally, the
Table VII. Change in treatment decision by the test score, pre-to post21-gene testing.

\begin{tabular}{lcccc}
\hline & Total & $\begin{array}{c}\text { Total change } \\
\text { rate, n }(\%)\end{array}$ & $\begin{array}{c}\text { CTX to HT, } \\
\text { n }(\%)\end{array}$ & $\begin{array}{c}\text { HT to CTX, } \\
\text { n }(\%)\end{array}$ \\
\hline 21-Gene RS & 227 & $78(34.4 \%)$ & $69(30.4 \%)$ & $9(4 \%)$ \\
Low & 139 & $67(48.2 \%)$ & $62(44.6 \%)$ & $5(3.6 \%)$ \\
Intermediate & 68 & $11(16.2 \%)$ & $7(10.3 \%)$ & $4(5.9 \%)$ \\
High & 20 & 0 & 0 & 0 \\
\hline
\end{tabular}

RS: Recurrence score; HT: hormone treatment; CTX: chemotherapy treatment.

treatment decision was changed in nine patients from no chemotherapy to chemotherapy based on the 21-gene RS result. The recommendation for chemotherapy decreased from $78(78.4 \%)$ patients to $47(33.4 \%)$ patients in the low-risk RS group $(n=139)$ and from $63(92.6 \%)$ to 60 patients $(88.2 \%)$ in the intermediate-risk RS group $(n=68)$.

Exploratory analysis. As previously reported, Ki67 expression correlated with the 21-gene RS. Most of the patients $(81.3 \%)$ with a low Ki67 expression level had a 21gene low RS, while $35.6 \%$ of the patients with a high Ki67 expression level had a 21-gene high RS. Furthermore, among the patients with low Ki67 expression, the proportion of patients (only 4.5\%) who should be administered chemotherapy was underestimated. We further found that patients with high Ki67 expression had a significantly higher probability of a high RS when compared with those with low Ki67 expression (relative rate $=4.6$, 95\% confidence interval $=1.7$ to 12.0. $p<0.001)$. Similarly, patients with a tumor size larger than $2 \mathrm{~cm}$ had a significantly higher risk score compared to those with a tumor size not larger than 2 $\mathrm{cm}$ (relative rate $=2.9,95 \%$ confidence interval $=1.1$ to 7.4 , $p=0.025)$. Finally, Ki67 expression and tumor size were significantly positively correlated with high 21-gene RS (Ki67, AUC=0.68; tumor size, $\mathrm{AUC}=0.62$; Figure 5).

\section{Discussion}

The current prospective study included a large sample size to investigate the impact of the 21-gene RS assay on adjuvant chemotherapy decision making in China. In this study, $61.2 \%, 30 \%$, and $8.8 \%$ of the patients were in the 21 gene low, intermediate and high RS groups, respectively. Furthermore, we found that $74.8 \%$ of the patients with a low RS were overestimated into the intermediate-risk group based on the St. Gallen risk score. In addition, the 21-gene RS test helped reduce chemotherapy use in $34.4 \%$. Interestingly, we found that for the prospective data, the Ki67 expression level correlated with the 21-gene risk score in $\mathrm{HR}^{+} / \mathrm{HER}^{-}{ }^{-} \mathrm{EBC}$. 
The role of the 21-gene RS test as an effective method to reduce adjuvant chemotherapy recommendations in $\mathrm{HR}^{+} / \mathrm{HER} 2^{-}$breast cancer has drawn increasing attention. However, the concordance of different methods for testing these 21 genes remains a matter of concern. Levine et al.'s study in Ontario enrolled 979 patients, and 58\%, 33\% and 9\% patients were classified into low-, intermediate- and high-risk groups, respectively, using the OncotypeDX test (24). Likewise, utilizing the branch DNA liquid chip method, we found that $61.2 \%, 30.0 \%$ and $8.8 \%$ of patients were classified into low-, intermediate-, and high-risk groups, respectively, which was quite similar to the results reported in the Ontario study.

Our results also showed that the 21-gene test reduced adjuvant chemotherapy use. Previous meta-analyses have shown that approximately $30 \%$ of treatment decisions are altered after performing the 21-gene RS test, with a $10 \%$ reduction in chemotherapy use $(16,25)$. Furthermore, Sun et al. reported that among 134 patients undergoing the 21-gene RS test, chemotherapy use was reduced in $29 \%$ (18). We observed that the 21 -gene RS results changed $33.4 \%$ of the chemotherapy recommendations for both node-negative and -positive breast cancer cases, which is quite consistent with findings from prospective studies, with rates ranging from $30 \%$ to $38 \%$ (24-27). Therefore, the 21-gene RS test should be performed regardless of N0 or N1 status, as reported previously $(28,29)$.

Most of the patients in the low-risk group would have obtained no benefit from the addition of adjuvant chemotherapy and could have avoided receiving chemotherapy. Previous data indicated that the 5-year rates of disease-free survival, distant metastasis-free survival and overall survival in patients with a low 21-gene RS were $93.8 \%, 99.3 \%$ and $98.0 \%$, respectively (30). In our study, of the 227 patients with an available 21 -gene RS test, $33.8 \%$, $88.2 \%$ and $100 \%$ in the low-, intermediate-, and high-risk groups, respectively, received adjuvant chemotherapy. We found that the 21-gene RS test reduced chemotherapy use from $78.4 \%$ prior to 21 -gene RS detection to $33.8 \%$ after the 21 -gene RS test, corresponding to a reduction of almost $45 \%$. Our study was more aggressive than previous studies in the determination of adjuvant chemotherapy $(28,31)$, as $89.4 \%$ of the patients in the 21 -gene RS low-risk subgroup belonged to the St. Gallen intermediate-risk group. Indeed, the St. Gallen risk score was shown to be an effective tool for adjuvant chemotherapy decision making (33).

In the era of precise medicine, it is important to determine which subgroups of patients should receive specific tests in order to save medical resources and reduce the financial burden. A variety of factors affect physicians when making the choice to use the 21-gene assay. For instance, age, race, socioeconomic status, marital status, insurance, geographic location, tumor grade, and tumor size have been reported as factors related to the application of the 21-gene assay (32-35). The median age in one study of 86,409 patients with EBC was 58 years (range $=19-90$ years), and $64 \%$ of these patients were the main group who underwent the assay (36). However, we did not find a significant correlation between age and a high 21-gene RS of the 227 patients. Furthermore, we did not observe evidence for a difference between younger and older patients with breast cancer. Thus, the role of age, suggested as a considerable factor, in selecting the choice of the 21-gene RS assay should be investigated further.

In addition, Ki67, a prognostic marker used to distinguish luminal subtype patients, has drawn recent attention (4). Molecular markers, including Ki67, are the main factors incorporated into the distinction between the luminal $\mathrm{A}$ and luminal B (HER2-negative) subtypes (32). Previously, a study reported that Ki67 was significantly associated with a greater likelihood of changing from hormone therapy to chemotherapy, while $\mathrm{PR}^{+}$status was associated with a greater likelihood of changing from chemotherapy to hormone therapy (27). Moreover, in a study with a small sample size, Verabadillo reported no significant correlation between Ki67 expression and the 21-gene RS (37). However, in contrast to this previous study, we observed that Ki67 was significantly positively correlated with the 21-gene RS, which is consistent with the study by Gluz et al. (38). In our study, we observed that ER, PR, Ki67 and tumor grade correlated with the 21-gene RS. Moreover, Ki67 showed an intermediate positive correlation with the 21-gene RS, and PR showed a minimal negative correlation with RS in our study. Obviously, Ki67 was not deemed a biomarker for selecting the 21-gene RS assay or not. Zhang et al.'s study showed that patients $(71.6 \%)$ with low Ki67 expression were more likely to undergo the 21-gene RS assay (18). In the present study, more patients $(81.6 \%)$ with low Ki67 expression underwent the 21-gene RS assay. However, in this study, only $4.5 \%$ of the patients with a Ki67 expression of less than $20 \%$ were finally classified into the high 21 -gene RS group. Conversely, among the patients with high Ki67 $(>20 \%$ ) breast cancer, up to $17.8 \%$ were classified in the high 21-gene RS group of N0-1 patients. Therefore, those patients with borderline Ki67 value should be encouraged to undergo the 21-gene RS test.

However, our study has certain limitations. Firstly, similarly to most previous studies, we prospectively performed the 21gene RS assay. However, we could not compare the prognosis among different risk groups because the follow-up duration was not long enough. To date, only one prospective study of 10,253 patients has provided prospective data regarding the correlation between the 21-gene risk score and 5-year disease recurrence and survival data (39). Secondly, the cost of the 21gene RS assay is so expensive nationwide that a number of patients were unable to receive it. Strategies of evaluation of adjuvant chemotherapy for EBC should be more available and 
affordable. Further study is needed of the correlation between 21-gene RS and Ki67.

In conclusion, this prospective study involving uniformly treated patients with $\mathrm{HR}^{+} / \mathrm{HER} 2^{-} \mathrm{N} 0-1$ breast cancer supports the ability of the 21-gene RS assay to identify patients who may be safely spared adjuvant chemotherapy. The use of the 21-gene RS test might ultimately result in a net reduction in treatment recommendations for adjuvant chemotherapy.

\section{Conflicts of Interest}

All Authors declare no conflict of interest in regard to this study

\section{Acknowledgements}

This work was supported by grants from the National Natural Science Foundation of China (81372819, 81502302, 81572596, U1601223), funding from Guangzhou Science and Technology Bureau (2014J4100170). This work was supported by Grant [2013]163 from Key Laboratory of Malignant Tumor Molecular Mechanism and Translational Medicine of Guangzhou Bureau of Science and Information Technology; Grant KLB09001 from the Key Laboratory of Malignant Tumor Gene Regulation and Target Therapy of Guangdong Higher Education Institutes Grant from Guangdong Science and Technology Department (2015B050501004). This work was supported by China Scholarship Council.

\section{References}

1 Chen W, Zheng R, Baade PD, Zhang S, Zeng H, Bray F, Jemal A, Yu XQ and He J: Cancer statistics in China, 2015. CA Cancer J Clin 66: 115-132, 2015.

2 Early Breast Cancer Trialists' Collaborative G: Effects of chemotherapy and hormonal therapy for early breast cancer on recurrence and 15-year survival: an overview of the randomised trials. Lancet 365: 1687-1717, 2005.

3 Cuzick J, Dowsett M, Pineda S, Wale C, Salter J, Quinn E, Zabaglo L, Mallon E, Green AR, Ellis IO, Howell A, Buzdar AU and Forbes JF: Prognostic value of a combined estrogen receptor, progesterone receptor, Ki-67, and human epidermal growth factor receptor 2 immunohistochemical score and comparison with the Genomic Health recurrence score in early breast cancer. J Clin Oncol 29: 4273-4278, 2011.

4 Jung SY, Han W, Lee JW, Ko E, Kim E, Yu JH, Moon HG, Park IA, Oh DY, Im SA, Kim TY, Hwang KT, Kim SW and Noh DY: $\mathrm{Ki}-67$ expression gives additional prognostic information on St. Gallen 2007 and Adjuvant! Online risk categories in early breast cancer. Ann Surg Oncol 16: 1112-1121, 2009.

5 Bauer K, Parise C and Caggiano V: Use of ER/PR/HER2 subtypes in conjunction with the 2007 St Gallen Consensus Statement for early breast cancer. BMC Cancer 10: 228, 2010.

6 Brufsky AM: Predictive and prognostic value of the 21-gene recurrence score in hormone receptor-positive, node-positive breast cancer. Am J Clin Oncol 37: 404-410, 2014.

7 Senkus E, Kyriakides S, Ohno S, Penault-Llorca F, Poortmans P, Rutgers E, Zackrisson S, Cardoso F and Committee EG: Primary breast cancer: ESMO Clinical Practice Guidelines for diagnosis, treatment and follow-up. Ann Oncol 26(Suppl 5): v8-30, 2015.
8 Gradishar WJ, Anderson BO, Balassanian R, Blair SL, Burstein HJ, Cyr A, Elias AD, Farrar WB, Forero A, Giordano SH, Goetz M, Goldstein LJ, Hudis CA, Isakoff SJ, Marcom PK, Mayer IA, McCormick B, Moran M, Patel SA, Pierce LJ, Reed EC, Salerno KE, Schwartzberg LS, Smith KL, Smith ML, Soliman H, Somlo G, Telli M, Ward JH, Shead DA and Kumar R: Invasive Breast Cancer Version 1.2016, NCCN Clinical Practice Guidelines in Oncology. J Natl Compr Canc Netw 14: 324-354, 2016.

9 Coates AS, Winer EP, Goldhirsch A, Gelber RD, Gnant M and Piccart-Gebhart M, Thurlimann B, Senn HJ, Panel M: Tailoring therapies--improving the management of early breast cancer: $\mathrm{St}$ Gallen International Expert Consensus on the Primary Therapy of Early Breast Cancer 2015. Ann Oncol 26: 1533-1546, 2015.

10 Albain KS, Barlow WE, Shak S, Hortobagyi GN, Livingston RB, Yeh IT, Ravdin P, Bugarini R, Baehner FL, Davidson NE, Sledge GW, Winer EP, Hudis C, Ingle JN, Perez EA, Pritchard KI, Shepherd L, Gralow JR, Yoshizawa C, Allred DC, Osborne CK and Hayes DF: Breast Cancer Intergroup of North A: Prognostic and predictive value of the 21-gene recurrence score assay in postmenopausal women with node-positive, oestrogenreceptor-positive breast cancer on chemotherapy: a retrospective analysis of a randomised trial. Lancet Oncol 11: 55-65, 2010.

11 Paik S, Shak S, Tang G, Kim C, Baker J, Cronin M, Baehner FL, Walker MG, Watson D, Park T, Hiller W, Fisher ER, Wickerham DL, Bryant J and Wolmark N: A multigene assay to predict recurrence of tamoxifen-treated, node-negative breast cancer. N Engl J Med 351: 2817-2826, 2004.

12 Mamounas EP, Tang G, Fisher B, Paik S, Shak S, Costantino JP, Watson D, Geyer CE Jr., Wickerham DL and Wolmark N: Association between the 21-gene recurrence score assay and risk of locoregional recurrence in node-negative, estrogen receptorpositive breast cancer: results from NSABP B-14 and NSABP B-20. J Clin Oncol 28: 1677-1683, 2010.

13 Jerzak KJ and Pritchard KI: The 21-gene recurrence score assay in node-negative early breast cancer: Prognostic, predictive or presumptuous? Eur J Cancer 68: 173-175, 2016.

14 Buus R, Sestak I, Kronenwett R, Denkert C, Dubsky P, Krappmann K, Scheer M, Petry C, Cuzick J and Dowsett M: Comparison of EndoPredict and EPclin with Oncotype DX Recurrence Score for prediction of risk of distant recurrence after endocrine therapy. $\mathrm{J}$ Natl Cancer Inst 108(11): djw149, 2016.

15 Albanell J, Svedman C, Gligorov J, Holt SD, Bertelli G, Blohmer JU, Rouzier R, Lluch A and Eiermann W: Pooled analysis of prospective European studies assessing the impact of using the 21-gene recurrence score assay on clinical decision making in women with oestrogen receptor-positive, human epidermal growth factor receptor 2-negative early-stage breast cancer. Eur J Cancer 66: 104-113, 2016.

16 Eiermann W, Rezai M, Kummel S, Kuhn T, Warm M, Friedrichs K, Schneeweiss A, Markmann S, Eggemann H, Hilfrich J, Jackisch C, Witzel I, Eidtmann H, Bachinger A, Hell S and Blohmer J: The 21-gene recurrence score assay impacts adjuvant therapy recommendations for ER-positive, node-negative and node-positive early breast cancer resulting in a risk-adapted change in chemotherapy use. Ann Oncol 24: 618-624, 2016.

17 Dinan MA, Mi X, Reed SD, Lyman GH and Curtis LH: Association between use of the 21-gene recurrence score assay and receipt of chemotherapy among medicare beneficiaries with early-stage breast cancer, 2005-2009. JAMA Oncol 1: 10981109, 2015. 
18 Zhang YN, Zhou YD, Mao F and Sun Q: Impact of the 21-Gene Recurrence Score Assay in adjuvant chemotherapy selection for node-negative, hormone receptor-positive breast cancer in the Chinese population. Neoplasma 62: 658-665, 2015

19 Edge S B, Compton C C: The American Joint Committee on Cancer: the 7th edition of the AJCC cancer staging manual and the future of TNM. Ann Surg Oncol 17(6): 1471-1474, 2010.

20 Carlson RW, Brown E, Burstein HJ, Gradishar WJ, Hudis CA, Loprinzi C, Mamounas EP, Perez EA, Pritchard K, Ravdin P, Recht A, Somlo G, Theriault RL, Winer EP and Wolff AC: NCCN Task Force Report: Adjuvant Therapy for Breast Cancer. J Natl Compr Canc Netw 4(Suppl 1): 1-26, 2006.

21 Lakhani SR, Ellis IO, Schnitt SJ, Tan PH, van de Vijver MJ eds: World Health Organisation Classification of Tumours of the Breast, Fourth Edition Lyon, France: IARC Press, 2012.

22 Cheang MC, Chia SK, Voduc D, Gao D, Leung S, Snider J, Watson M, Davies S, Bernard PS, Parker JS, Perou CM, Ellis MJ and Nielsen TO: Ki67 index, HER2 status, and prognosis of patients with luminal B breast cancer. J Natl Cancer Inst 101(10): 736-750, 2009.

23 Goldhirsch A, Wood WC, Gelber RD, Coates AS, Thurlimann B and Senn HJ: Progress and promise: highlights of the International Expert Consensus on the Primary Therapy of Early Breast Cancer 2007. Ann Oncol 18: 1133-1144, 2007.

24 Levine MN, Julian JA, Bedard PL, Eisen A, Trudeau ME, Higgins B, Bordeleau L and Pritchard KI: Prospective evaluation of the 21-gene recurrence score assay for breast cancer decisionmaking in Ontario. J Clin Oncol 34: 1065-1071, 2016.

25 Augustovski F, Soto N, Caporale J, Gonzalez L, Gibbons L and Ciapponi A: Decision-making impact on adjuvant chemotherapy allocation in early node-negative breast cancer with a 21-gene assay: systematic review and meta-analysis. Breast Cancer Res Treat 152: 611-625, 2015.

26 Lo SS, Mumby PB, Norton J, Rychlik K, Smerage J, Kash J, Chew HK, Gaynor ER, Hayes DF, Epstein A and Albain KS: Prospective multicenter study of the impact of the 21-gene recurrence score assay on medical oncologist and patient adjuvant breast cancer treatment selection. J Clin Oncol 28: 1671-1676, 2010.

27 Albanell J, Gonzalez A, Ruiz-Borrego M, Alba E, Garcia-Saenz JA, Corominas JM, Burgues O, Furio V, Rojo A, Palacios J, Bermejo B, Martinez-Garcia M, Limon ML, Munoz AS, Martin M, Tusquets I, Rojo F, Colomer R, Faull I and Lluch A: Prospective transGEICAM study of the impact of the 21-gene recurrence score assay and traditional clinicopathological factors on adjuvant clinical decision making in women with estrogen receptor-positive $(\mathrm{ER}+)$ node-negative breast cancer. Ann Oncol 23: 625-631, 2012.

28 Parsons BM, Landercasper J, Smith AL, Go RS, Borgert AJ and Dietrich LL: 21-Gene recurrence score decreases receipt of chemotherapy in ER+ early-stage breast cancer: an analysis of the NCDB 2010-2013. Breast Cancer Res Treat 159: 315-326, 2016.

29 Gligorov J, Pivot XB, Jacot W, Naman HL, Spaeth D, Misset JL, Largillier R, Sautiere JL, de Roquancourt A, Pomel C, Rouanet P, Rouzier R, Penault-Llorca FM, and Francilian Breast Intergroup: Prospective clinical utility study of the use of the 21gene assay in adjuvant clinical decision making in women with estrogen receptor-positive early invasive breast cancer: Results From the SWITCH Study. Oncologist 20: 873-879, 2015.
30 Sparano JA, Gray RJ, Makower DF, Pritchard KI, Albain KS, Hayes DF, Geyer CE Jr., Dees EC, Perez EA, Olson JA, Jr., Zujewski J, Lively T, Badve SS, Saphner TJ, Wagner LI, Whelan TJ, Ellis MJ, Paik S, Wood WC, Ravdin P, Keane MM, Gomez Moreno HL, Reddy PS, Goggins TF, Mayer IA, Brufsky AM, Toppmeyer DL, Kaklamani VG, Atkins JN, Berenberg JL and Sledge GW: Prospective validation of a 21-gene expression assay in breast cancer. N Engl J Med 373: 2005-2014, 2015.

31 Ozmen V, Atasoy A, Gokmen E, Ozdogan M, Guler N, Uras C, Ok E, Demircan O, Isikdogan A and Saip P: Impact of Oncotype DX Recurrence Score on treatment decisions: results of a prospective multicenter study in Turkey. Cureus 8: e522, 2016.

32 Goldhirsch A, Winer EP, Coates AS, Gelber RD, Piccart-Gebhart M, Thurlimann B, Senn HJ and Panel M: Personalizing the treatment of women with early breast cancer: highlights of the St Gallen International Expert Consensus on the Primary Therapy of Early Breast Cancer 2013. Ann Oncol 24: 2206-2223, 2013.

33 Lynch JA, Berse B, Petkov V, Filipski K, Zhou Y, Khoury MJ, Hassett $M$ and Freedman AN: Implementation of the 21-gene recurrence score test in the United States in 2011. Genet Med 18: 982-G90, 2016.

34 Afghahi A, Mathur M, Thompson CA, Mitani A, Rigdon J, Desai M, Yu PP, de Bruin MA, Seto T, Olson C, Kenkare P, Gomez SL, Das AK, Luft HS, Sledge GW, Jr., Sing AP and Kurian AW: Use of gene expression profiling and chemotherapy in early-stage breast cancer: a study of linked electronic medical records, cancer registry data, and genomic data across two health care systems. J Oncol Pract 12: e697-709, 2016.

35 Jasem J, Amini A, Rabinovitch R, Borges VF, Elias A, Fisher $\mathrm{CM}$ and Kabos P: 21-Gene recurrence score assay as a predictor of adjuvant chemotherapy administration for early-stage breast cancer: an analysis of use, therapeutic implications, and disparity profile. J Clin Oncol 34: 1995-2002, 2016.

36 Orucevic A, Heidel RE and Bell JL: Utilization and impact of 21-gene recurrence score assay for breast cancer in clinical practice across the United States: lessons learned from the 2010 to 2012 National Cancer Data Base analysis. Breast Cancer Res Treat 157: 427-435, 2016.

37 Verabadillo FE: Association between androgen receptor expression, Ki-67 and the 21-gene recurrence score in nonmetastatic, lymph node-negative, estrogen receptor-positive and HER2-negative breast cancer. J Clin Pathol 68: 839-843, 2015.

38 Gluz O, Nitz UA, Christgen M, Kates RE, Shak S, Clemens M, Kraemer S, Aktas B, Kuemmel S, Reimer T, Kusche M, Heyl V, Lorenz-Salehi F, Just M, Hofmann D, Degenhardt T, Liedtke C, Svedman C, Wuerstlein R, Kreipe HH and Harbeck N: West German Study Group Phase III PlanB Trial: First prospective outcome data for the 21-gene recurrence score assay and concordance of prognostic markers by central and local pathology assessment. J Clin Oncol 34: 2341-2349, 2016.

39 Baker H: 21-gene assay identifies patients who can avoid chemotherapy. Lancet Oncol 16: e531, 2015.

Received May 2, 2017

Revised June 8, 2017 Accepted June 13, 2017 